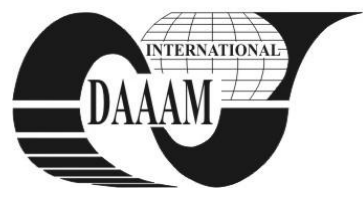

Annals of DAAAM for 2011 \& Proceedings of the 22nd International DAAAM Symposium, Volume 22, No. 1, ISSN 1726-9679 ISBN 978-3-901509-83-4, Editor B. Katalinic, Published by DAAAM International, Vienna, Austria, EU, 2011 Make Harmony between Technology and Nature, and Your Mind will Fly Free as a Bird

Annals \& Proceedings of DAAAM International 2011

\title{
MINITHIXOFORMING OF HIGH CHROMIUM TOOL STEEL X210CR12 WITH VARIOUS INITIAL STATES
}

\author{
MASEK, B[ohuslav]; VANCURA, F[ilip]; AISMAN, D[avid] \& JIRKOVA, H[ana]
}

\begin{abstract}
When processing using a variety of technologies, materials carry their history, which is also reflected in changes in their structure. Various technologies are reflected in the development of structures with varying intensity. This article shows the influence of processing semi-finished X210Cr12steel on the history of the development of structures in the thixoforming process. In this work two states were compared with different initial structures which were subjected to free deformation in the semi-solid state. Experimental results show that in these cases, the sensitivity to the accuracy of the initial attributes of the initial structures are very low and there was no significant modification of the structure after thixoforming.
\end{abstract}

Key words: thixoforming, minithixoforming, semi-solid state, X210Cr12 tool steel

\section{INTRODUCTION}

Thixoforming is an innovative technology with its first industrial results, especially in aluminium and magnesium alloys (Püttgen et al., 2007). Thixoformed material is formed in the semi-solid state. The ideal ratio between the solid and liquid component is, according to the alloys used, considered to be 6:4. After the transition to the semi-solid state, the system has a relatively high viscosity, which decreases sharply with shear deformation. The advantages of this processing are the complex shape of the final product, which may be due to unconventional structures, and also very interesting mechanical properties.

For many reasons, thixoformed steel has not yet found wide application in industry. One reason is that ways of competing with die forging are especially being sought. Thixoforming of steels and alloys with high melting points can show interesting results, also in terms of achieved structures (Masek et al., 2010, Aišman et al, 2008).

This paper is focused on the development of microstructures during forming in the semi-solid state and seeks an answer to the question: with what intensity does the deformed semi-product in the semi-solid state carry the structural attributes and history of its previous treatment?

\section{EXPERIMENT}

Tool steel $\mathrm{X} 210 \mathrm{Cr} 12$ was chosen as the experimental material. The main reason is the wide interval between the solidus and liquidus, which is suitable for carrying out experiments in the semi-solid state. The material was delivered as a rolled rod in the soft annealed state with a hardness of $211 \mathrm{HV} 30$.

The experiment was performed on equipment developed for forming small parts in the semi-solid state. This process is called minithixoforming (Jirková, et al., 2010, Aišman et al., 2010). A key device in this process enables high-frequency resistance heating of the input stock. This allows the desired temperature to be reached with high velocity heating and high- precision control of the temperature field. The stock is heated between two copper electrodes inside the form. This eliminates complex material handling in the semi solid state. Forming takes place after reaching the exact temperature.

\begin{tabular}{|l|l|l|l|l|l|l|}
\hline $\mathrm{C}$ & $\mathrm{Cr}$ & $\mathrm{Mn}$ & $\mathrm{Si}$ & $\mathrm{Ni}$ & $\mathrm{P}$ & $\mathrm{S}$ \\
\hline $1.8-$ & $11-$ & $0.2-$ & $0.2-$ & $\max$. & $\max$. & $\max$. \\
2.05 & 12.5 & 0.45 & 0.45 & 0.5 & 0.03 & 0.035 \\
\hline
\end{tabular}

Tab. 1. Standard chemical composition of X210Cr12 steel given in wt.\%

\subsection{Semi-Products}

Two initial states were chosen for the experiment. The first state was the state as supplied by the manufacturer. The second state was prepared by thermal twenty-step rapid cycling heat treatment (CHT) through the interval of temperatures above the $A_{c 3}$ to $M_{s}$ in order to obtain a finer-grained structure. From these two initial states were prepared input stock for minithixo forming.

The microstructure of the material supplied by the manufacturer was composed of a mixture of ferrite, globular cementite and primary chromium carbides. The average grain size was $13 \mu \mathrm{m}$ and hardness was $211 \mathrm{HV} 30$. In the second case, after thermal cycling with a rapid final cooling, the structure consisted of martensite and primary carbides of chromium, with an average grain size of 1 micron with a hardness of 595 HV30 (Tab. 2). The microstructures of both initial states were too complicated to determine the grain size by conventional optical methods because the high angle grain boundaries were not visually distinguishable. Therefore, EBSD analysis was used to determine the grain size.

\subsection{Treatment in semi-solid state}

Input stock was subjected to the following experimental conditions. The material was heated to the semi solid state at a temperature of $1265{ }^{\circ} \mathrm{C}$ in $55 \mathrm{~s}$. Forming temperature was calculated in JMatPro. At this temperature, the proportion of the liquid phase is approximately $33 \%$. Once the temperature reached $1265{ }^{\circ} \mathrm{C}$, the material was compressed from a $6 \mathrm{~mm}$ length to about $2 \mathrm{~mm}$ for $0.3 \mathrm{~s}$ and then immediately cooled in water-air mixture to room temperature. The deformation corresponds to about $30 \%$.

To determine the size of globular and polyhedral particles of austenite modified interception method was used. Together with the analysis of microstructures, the hardness was measured (Tab 2.)

The structure after deformation in the semi-solid state was, as expected, in both cases composed of globular and polyhedral formations of austenite embedded in a eutectic network. In both cases, nearly the same average values of size of austenitic formations were measured, ranging from 10 to $13 \mu \mathrm{m}$. The differences were only observed in the hardness values, where a hardness of 357 was measured, actually 393 HV30 (Tab 2). 
The measured differences in hardness could have several causes. One possible reason could be the difference in the character of the eutectic network. For this purpose, the analysis was performed by REM. The eutectic network had a lamellar character (Fig. 1.) and locally differed only in the shape of lamellas depending on the gradient of heat dissipation during intense cooling from the semi-solid state. Comparison of the two treated semi-products, however, reveals no significant differences in their morphologies.

Another possible reason for the results from measuring the grain size of the final structure could be the deformation input to the forming process, which is not enough for sufficient plastic deformation of austenite grains to lead to their eventual refinement. An interesting finding in the austenitic grains was the incidence of twins, which may have different origins. Their presence was confirmed in both cases and their origin has not yet been fully elucidated and will be the subject of further research. At the same time in the interior of the grains austenitic chemical heterogeneity was found caused by imperfect redistribution of the original primary chromium carbides (Fig. 2). This fact was documented by EDX analysis.

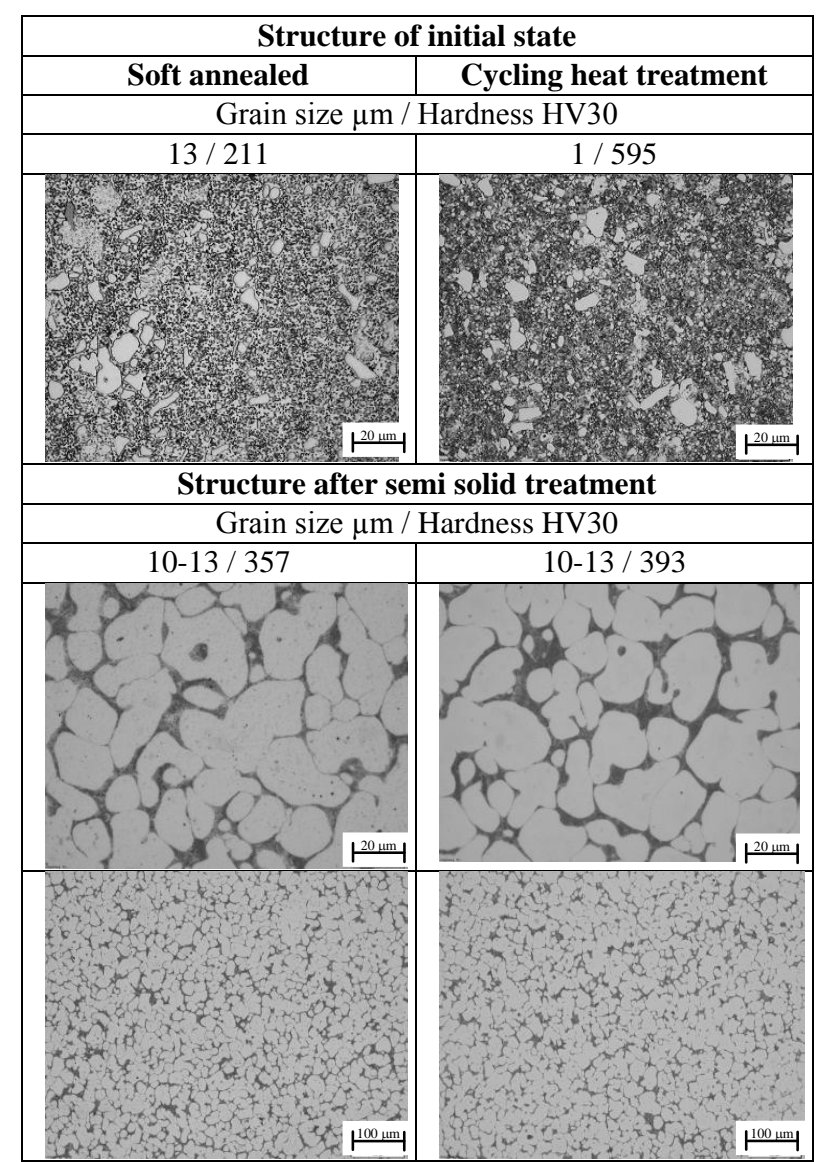

Tab. 2. Development of microstructure

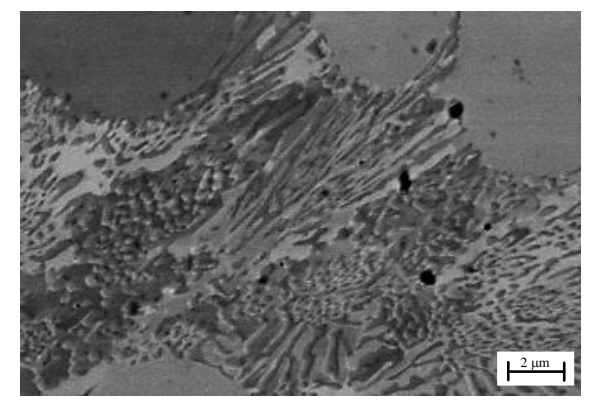

Fig. 1. Eutectic network

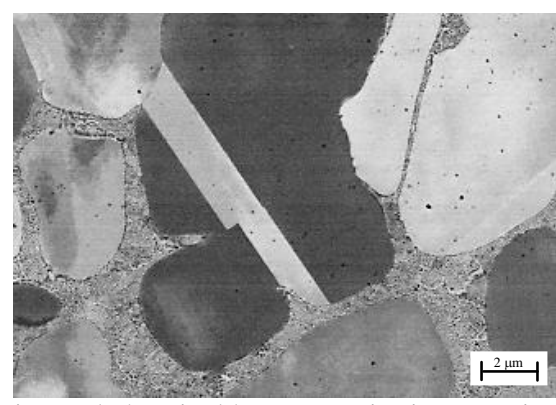

Fig. 2. Twins and chemical heterogeneity in austenite

\section{CONCLUSION}

The experiment showed that thixoforming is a process with a very intense influence on structural development. Intervention into the structure of the semi-product leading to a refinement of the structure was carried out by multiple thermal cycles through the range of temperatures from above $A_{c 3}$ to below $M_{s}$. The result of final rapid cooling was a structure composed of fine grained marten site and primary chromium carbides, which remained without significant changes. This refinement of the resulting structure after deformation in the semi-solid state did not occur. The structures of both initial states after thixoforming were composed of globular and polyhedral austenite, embedded in the eutectic network. The average size of austenitic units ranged from 10 to $13 \mu \mathrm{m}$ and corresponded with the original grain size in the as-delivered state. The technological process parameters will be dealt with in the next phase of the experiment, especially the size and amount of deformation and value of the forming temperature.

\section{ACKNOWLEDGEMENTS}

This paper includes results obtained under the project No. GA ČR P107/11/J083, The Influence of Input Microstructure on Final Properties of Material Processed by Mini-thixoforming and the project No. 1M06032, Research Centre of Forming Technology. The projects are funded from specific resources of the state budget for research and development.

\section{REFERENCES}

Aišman, D., Behúlová, M., Jirková, H., Mašek, B. (2010). Microstructure and Phase Composition of Steel X210Cr12 after the Forming in Semi-Solid State. Proceedings of $23^{\text {rd }}$ International Conference on Heat Treatment, Jihlava, Czech Republic, ISBN 978-80-904462-3-6, Association for the heat treatment of metals: Ecosond, Prague

Aišman, D., Jirková, H., Mašek, B. (2009). Forming Technology of Small Parts in Semi-solid State. Proceedings of the 20th International DAAAM Symposium Intelligent Manufacturing \& Automation: Theory, Practice \& Education, Vol. 20, No. 1, Vienna, ISSN 1726-9679, ISBN 978-3-901509-70-4, Katalinic, B.(Ed.), pp. 18951896, DAAAM International, TU Vien, Vienna

Jirková, H., Aišman, D.,Mašek B. (2010). Unconventional Structure of X210Cr12 Steel Obtained by Thixoforming. Journal of Alloys and Compounds, Vol.504, No.1, August 2010 pp. 500-503, ISSN 0925-8388

Mašek, B., Aišman, D., Behúlová, M., Jirková, H. (2010). Structure of Miniature Components from Steel Produced by Forming in Semi-Solid State. Trans. Nonferrous Met. Soc. China 20, Vol. 20, No.3, September 2010 pp. 1037- 1041., ISSN 1003-6326

Püttgen, W., Bleck, W., Hirt, G., Shimahara, H. (2007). Thixoforming of Steels - A Status Report. Advanced Engineering Materials, Vol. 9, No. 4, April 2007 pp. 231245, ISSN 0255-5476 